\title{
PENGOLAHAN SAMPAH ORGANIK PASAR DENGAN MENGGUNAKAN MEDIA LARVA BLACK SOLDIER FLIES (BSF)
}

\author{
Sri Widyastuti ${ }^{2}$, Sardin $^{1)}$ \\ 1) 2) Program Studi Teknik Lingkungan, Fakultas Teknik, \\ Universitas PGRI Adi Buana Surabaya \\ email: sardinsipanyong@gmail.com ${ }^{1)}$,rafirudi@yahoo.co.id ${ }^{2)}$
}

\begin{abstract}
ABSTRAK
Sampah organik pasar belum bisa langsung diolah menjadi kompos dengan menggunakan media yang berisi larva black soldier fly (maggot), hal ini disebabkan karena kadar air terlalu tinggi. Tujuan penelitian ini adalah untuk mengolah sampah organik pasar menjadi kasgot (kompos bekas maggot). Treatment dalam penelitian ini adalah penjemuran, penambahan telur black soldier fly dan penambahan kompos stater pada media pengkomposan untuk treatment 1 dan 3 . Parameter yang diujikan adalah $\mathrm{C} / \mathrm{N}$ rasio; kondisi fisik,mikroba dan kecepatan proses pengomposan. Hasil penelitian berdasarkan SNI Kompos 19-7030-2004 tentang Spesifikasi Kompos dari Sampah Organik Domestik. menunjukkan karakteristik kompos pada penjemuran selama 2 hari lebih baik daripada penjemuran selama 3 hari. Jenis mikroba yang paling dominan ditemukan pada pengolahan sampah organik pasar dengan menggunakan media BSF yaitu jenis mikroba Bacillus $s p$.
\end{abstract}

Kata Kunci: kompos, larva black soldier fly, sampah organik pasar,

\section{ABSTRACT}

Wet organic waste cannot be processed directly into compost using media containing black soldier fly (maggot) larvae, this is because the water content is too high. The purpose of this research is to process wet organic waste into kasgot (used compost maggot). The treatments in this study were drying, adding black soldier fly eggs and adding stater compost to the composting media for treatment 1 and 3. The parameters tested were C / N ratio; physical conditions, microbes and speed of the composting process. The results of the research are based on SNI Compost 19-7030-2004 regarding Compost Specifications from Domestic Organic Waste. Showed that compost characteristics in drying for 2 days are better than drying for 3 days. The most dominant type of microbe found in market organic waste processing using BSF media is the type of microbe Bacillus sp.

Keywords: compos, larvae black sholdier fly, , wet organic waste, 


\section{PENDAHULUAN}

Tahun 2016 jumlah timbulan sampah di Indonesia mencapai 65.200.000 ton per tahun dengan penduduk sebanyak 261.115.456 orang (Subdirektorat Statistik Lingkungan Hidup, 2018). Proyeksi penduduk Indonesia menunjukkan angka penduduk yang terus bertambah dan tentunya akan meningkatkan jumlah timbulan sampah. Harus dilakukan suatu upaya agar Target SDGs 12.5 yang menyatakan negara secara substansial mengurangi timbulan sampah melalui pencegahan, pengurangan, daur ulang, dan penggunaan kembali dapat dicapai. Langkah pemerintah tertuang dalam Pepres 97 Tahun 2017 yang menargetkan pengurangan sampah rumah tangga. Berdasarkan laporan Badan Pengkajian dan Penerapan Teknologi tahun 2010, persentase sampah organik mencapai $65,05 \%$ (BPPT, 2010). Kusnadi et al., (2009) menyebutkan dari total sampah organik kota, sekitar $60 \%$ merupakan sampah sayuran dan $40 \%$ merupakan gabungan sampah kebun, kulit buah-buahan, dan sisa makanan. Berdasarkan persentase di atas akan diperoleh timbulan sampah makanan sangat tinggi apabila langsung dibuang ke TPA tanpa pengolahan terlebih dahulu. Didukung faktor tersebut, pemanfaatan larva black soldier fly untuk mereduksi sampah makanan layak untuk dikembangkan.

Kemampuan black soldier fly dalam memakan sampah organik membuatnya banyak digunakan sebagai salah satu agen dekomposter. Menurut Diener et al. (2011), black soldier fly dapat mencerna sampah organik dengan pengurangan sampah organik sebesar $65.5 \%$ hingga $78.9 \%$ per hari dari jumlah makanan yang didapatkannya. Dekomposisi biologis yang terjadi pada saat pengomposan secara umum dibantu oleh bakteri, actinomycetes, jamur, protozoa, cacing, dan beberapa jenis larva. Tetapi, komunitas mikroba ini sangat dipengaruhi oleh fase mesofilik dan fase termofilik selama proses pengomposan dan juga dipengaruhi oleh sifat fisik dari bahan awal limbah (Varma, dkk, 2017). Kemampuan black soldier fly dalam pengolahan bahan organik disebabkan oleh sistem pencernaannya yang memiliki mikrobium alami yang membantu proses dekomposisi bahan organik. Menurut Yu et al. (2011), black soldier fly memiliki beragam bakteri simbiosis termasuk Bacillus sp. Mikroba tersebut bermanfaat sebagai agen pengendali pathogen tanaman. Selain itu, bakteri ini juga dapat bermanfaat sebagai rizhobacteria pada tanaman. Sehingga kompos bekas maggot (larva black soldier fly) baik digunakan untuk pupuk.

Larva black soldier fly juga dapat mengolah bahan organik menjadi produk yang digunakan sebagai pupuk. Kandungan nutrisi yang terdapat dalam produk komersial yang terdapat di pasaran, sehingga produk padat tersebut dapat dijadikan pengganti pupuk kompos (Yudi Sastro,2016). Larva black soldier fly memiliki kemampuan yang baik untuk mendegradasi limbah organik diindikasi oleh kandungan nutrisi dari larva black soldier fly (Fahmi, 2015). Kualitas nutrisi yang diberikan kepada larva black soldier fly pada saat budi daya, menjadi penting karena berpengaruh terhadap masa tubuh dan ukuran individu larva black soldier fly yang dihasilkan. Hal tersebut memungkinkan untuk memaksimalkan produksi telur secara masal yang berkesinambungan dalam budidaya black soldier fly (Gobbi et al., 2013).

Banyaknya manfaat yang dapat diperoleh dari proses penguraian sampah organik oleh black soldier fly. Selain diperoleh larva yang dapat digunakan sebagai pakan ternak, juga membantu dalam proses pengomposan. Proses pengomposan membutuhkan waktu yang lebih singkat dan cepat, dibandingkan pengomposan tanpa black soldier fly. Pengomposan dengan bantuan black sholdier fly dapat berlangsung dalam waktu 12 hari.

Pemahaman siklus hidup akan dapat membantu untuk mengerti mengapa black soldier fly merupakan jenis serangga yang tepat untuk pengelolaan sampah organik. Selain itu pemahaman ini juga dapat memudahkan dalam mempelajari bagaimana siklus ini dapat "direkayasa" untuk meningkatkan manfaat yang didapat dari efisiensi sampah dan panen produk, baik secara kuantitas maupun kualitas.

Namun yang menjadi kendala dalam pemanfaatan sampah pasar untuk di olah 
menjadi maggot adalah kadar air sampah. Sampah pasar terlalu basah sehingga proses penguraian sampah pasar menjadi maggot tidak berjalan dengan sempurna. Kualitas kompos yang dihasilkan juga tidak akan memenuhi baku mutu kompos.

Black Soldier Fly (BSF) atau dalam bahasa latin Hermetia illucens merupakan spesies lalat dari ordo Diptera dan famili Stratiomyidae dengan genus Hermetia. Black Soldier Fly adalah spesies lalat tropis yang mempunyai kemampuan mengurai materi organik dengan sangat baik (Holmes, dkk, 2012).

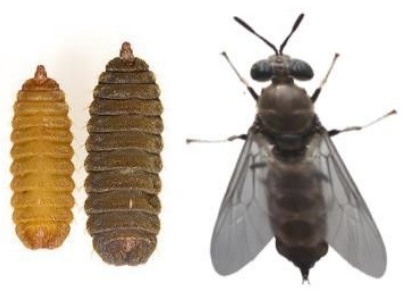

Gambar 1. Morfologi Larva, Pupa, dan Lalat

Dewasa BSF (Sumber: Wardhana, 2016)

Black Soldier Fly mampu mengekstrak energi dan nutrien dari sisa sayuran, sisa makanan, bangkai hewan, dan sisa kotoran lainnya, seperti tinja dan air limbah domestik sebagai makanannya. Larva atau maggot dari black soldier fly dapat mendaur ulang sampah jenis padat maupun cair, serta cocok untuk dikembangbiakan secara monokultur karena mudah disebarkan, aman, dan mudah dikembangbiakan di semua kondisi. Selain itu, tidak mudah terpengaruh oleh mikroorganisme dan tidak mudah terjangkit parasit. Black Soldier Fly juga mampu bertahan dalam kondisi ekstrem dan mampu bekerjasama dengan mikroorganisme untuk mendegradasi sampah organik. Black Soldier Fly bukan hama (Popa, 2012), tetapi merupakan jenis lalat yang memiliki risiko penyebaran penyakit yang lebih rendah dibanding jenis lalat lainnya (Bullock, dkk, 2013).

Konversi materi organik oleh larva black soldier fly (maggot) merupakan teknologi daur ulang sampah memiliki potensi ekonomi cukup tinggi (Diener, 2010). Black Soldier Fly menguntungkan, karena maggot memanfaatkan sampah organik, baik dari hewan, tumbuhan, maupun kotoran manusia sebagai makanannya, serta meningkatkan nilai daur ulang dari sampah organik.

Beberapa penelitian juga menunjukkan bahwa maggot dapat mendegradasi sampah organik dari hewan maupun tumbuhan lebih baik dibandingkan serangga lainnya yang pernah diteliti (Kim, dkk, 2010). Maggot mampu mengonversi sejumlah besar limbah organik menjadi biomassa kaya protein untuk mengganti tepung ikan (Diener, dkk, 2009). Maggot telah dipropagasikan sebagai agen konverter limbah organik, karena larva ini memakan berbagai bahan organik yang membusuk, serta menghasilkan prepupa yang mengandung protein kasar $40 \%$ dan $30 \%$ lemak. Oleh karena itu maggot dapat digunakan sebagai pakan ikan dan hewan ternak lainnya seperti ayam dan burung berkicau. Selain pengurangan limbah dan stabilisasi, produk dalam bentuk prepupa menawarkan pakan hewan ternak bernilai tambah dan membuka peluang ekonomi baru bagi pengusaha kecil di negara berkembang (Nguyen, dkk, 2015).

Larva black soldier fly yang dipanen dapat berguna sebagai sumber protein untuk pakan hewan, sehingga dapat dijadikan sebagai pakan alternative pengganti pakan konvensional (Dortmans et al. 2017). Harlystiarini (2017) menyatakan bahwa kandungan lemak tepung larva black soldier fly cukup tinggi yakni $27,36 \%$ di bandingkan dengan kandungan lemak tepung pada meat bone meal (MBM) yang hanya sebesar $5,59 \%$. 
Hasil akhir proses biokonversi, yaitu perubahan komposisi bahan organik sampah akibat penguraian oleh larva black soldier fly menjadi senyawa organik yang lebih sederhana. Hasil biokonversi dari larva black soldier fly menghasilkan bahan stabil, seperti kompos. Kompos adalah bentuk akhir dari bahan bahan organik sampah setelah mengalami dekomposisi atau konversi.

Pada umumnya sampah organik yang bersifat lunak namun tidak mengandung kadar air yang tinggi, di daur ulang dengan menggunakan teknologi pengomposan (Gani, 2007), selain itu juga dilakukan peruraian secara anaerob untuk menghasilkan bio gas (Davis et al., 2014)

Kadar air yang tinggi merupakan penyebab sulitnya larva mereduksi pakan (Hakim dkk, 2017). Tran, dkk., dalam Muhayyat (2016) juga menyatakan bahwa kadar air media pembudidayaan larva harus rendah dikarenakan larva tidak dapat tumbuh pada media dengan kadar air yang tinggi. Pertumbuhan maggot sangat ditentukan oleh media dimana maggot tersebut tumbuh. Jenis lalat $H$. illucens menyukai aroma media yang khas tetapi tidak semua media dapat dijadikan sebagai tempat bertelur bagi lalat $H$. Illucens (Tomberlin et al. 2018).

Berdasar latar belakang tersebut maka penelitian ini di lakukan untuk memecahkan masalah yakni: menentukan lama penjemuran sampah pasar yang paling baik, penambahan telur larva (maggot) black soldier fly dan penambahan kompos stater untuk dapat menghasilkan kompos yang baik sesuai SNI Kompos 197030-2004. Spesifikasi Kompos dari Sampah Organik Domestik. Parameter yang di ukur sesuai SNI 19-7030-2004 adalah harga $\mathrm{C} / \mathrm{N}$ rasio, $\mathrm{pH}$, suhu, kelembaban, lama waktu pengomposan, dan jenis mikrooganisme yang paling dominan pada proses pengomposan setelah perlakuan dengan di jemur selama 2 hari dan 3 hari.

\section{METODE}

\section{Lokasi Penelitian}

Penelitian di lakukan di Pusat Daur Ulang Jambangan Kecamatan Jambangan Kota Surabaya

\section{Alat dan Bahan Penelitian}

Alat penelitian berupa peralatan pemeliharaan larva BSF, yaitu tray industri (DOL), wadah plastik $12 \mathrm{~cm} \times 5$ $\mathrm{cm} \times 12 \mathrm{~cm}$, kain kasa, ember, timbangan, mesin pengayak

Bahan :, telur larva seberat 20 gram dan 40 gram , kompos stater, sampah pasar,

\section{Pelaksanaan Penelitian}

Penelitian dilakukan sebagai berikut

Kontrol : Penjemuran sampah pasar selama 1 hari

Treatment I: Penjemuran sampah pasar selama 2 hari dilanjutkan dengan proses pengomposan dimana media untuk pengomposan selain diberi telur maggot seberat 20 gram juga ditambah kompos stater. Treatment II: Penjemuran sampah pasar selama 2 hari, dilanjutkan dengan proses pengomposan dimana media untuk pengomposan diberi telur maggot seberat 20 gram tanpa ditambah kompos stater. Treatment III: Penjemuran sampah pasar selama 3 hari dilanjutkan dengan proses pengomposan dan diberi telur maggot seberat 40 gram dan ditambah dengan kompos stater. Treatment IV : Penjemuran sampah pasar selama 3 hari dilanjutkan proses pengomposan dimana media diberi dengan telur maggot seberat 40 gram tanpa ditambah kompos stater. Masing masing perlakuan dilakukan pengulangan sebanyak 3 kali .

Proses pengomposan dilakukan melalui empat tahap. Yang pertama dimulai dari mencampurkan 4 kilogram sampah organik, ditambahkan dengan kompos stater (perlakuan 1 dan 3) dan telur larva sebanyak 20 gr untuk perlakuan 1 dan 2, telur larva sebanyak 40 gr untuk perlakuan 3 dan 4 . Lima hari kemudian, larva diberi kan sampah organik lagi (fidding 11) sebanyak 3 kilogram. Tiga hari berikutnya, tahap ke tiga (fidding 111) larva diberikan sampah organik 3 kilogram. Jarak empat hari, tahap ke empat adalah panen, larva dipisahkan dengan kotorannya dengan alat Sieving Machine.

Parameter yang akan diteliti pada penelitian ini adalah $\mathrm{C} / \mathrm{N}$ rasio, kondisi fisik kompos ( $\mathrm{pH}$, suhu dan kelembaban), kecepatan pengomposan dan jenis mikroba pengurai. Analisis parameter dilakukan di 
Laboratorium Gizi Fakultas Kesehatan Masyarakat Universitas Airlangga. Telor black soldier fly berasal dari Pasar Puspa
Agro (Sidoarjo) sebagai lokasi pembibitan BSF.

\section{HASIL DAN PEMBAHASAN} berikut:

Hasil keseluruhan perlakuan terhadap karakteristik kompos sampah pasar adalah sebagai

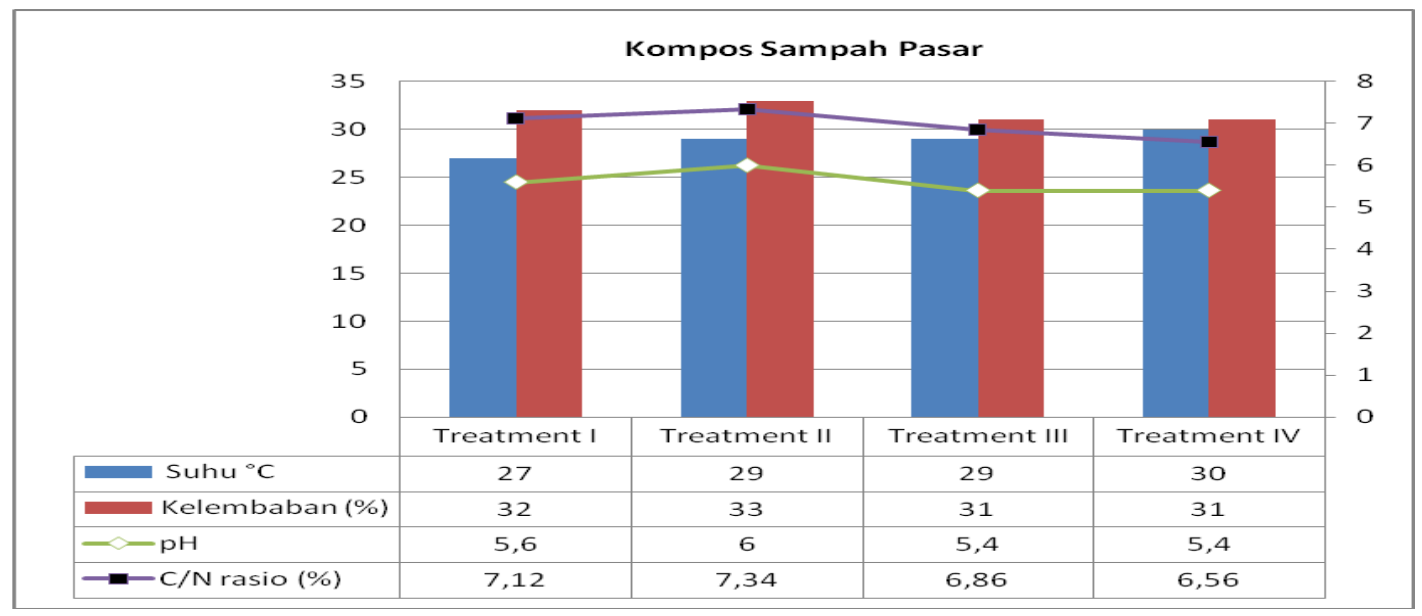

Gambar 2. Karakteristik Kompos Sampah Pasar

Proses pengomposan sampah pasar menggunakan media larva black soldier fly dengan ditambahkan dengan kompos stater tidak menghasilkan perbedaannya signifikan. Untuk hasil pengomposan dengan menambahkan kompos stater pada media pengomposan memberikan waktu pengomposan 1 hari lebih cepat dibandingan dengan tidak menggunakan kompos stater.

Hasil $\mathrm{C} / \mathrm{N}$ rasio tertinggi terlihat pada Treatment I yitu penjemuran sampah selama 2 hari, proses pengomposan selama 12 hari. Meskipun demikian angka $\mathrm{C} / \mathrm{N}$ rasio yang didapatkan belum memenuhi baku mutu yang disyaratkan dalam SNI 19-7030-2004. Pengaruh jenis campuran sampah yang digunakan juga sangat menentukan terhadap hasil $\mathrm{C} / \mathrm{N}$ rasio kompos matang (Widarti, 2015). Demikian pula halnya dengan kelembaban kompos dan suhu, kelembaban dan suhu kompos melebihi baku mutu yang disyaratkan dalam SNI 19-7030-2004. Hal ini menunjukan kompos perlu di stabilkan dengan penambahan air secara kontinyu. Namun $\mathrm{pH}$ kompos telah memenuhi baku mutu .

Mikroorganisme yang terdapat pada pengomposan sampah pasar yang menggunakan kompos stater dan tanpa kompos stater yaitu Treatment I dan III memiliki mikroba yang lebih banyak karena tidak hanya ada mikroba pengurai karbohidrat juga mikroba pengurai lemak dan protein. Mikroba yang paling dominan dari beberapa Treatment I,II,III dan IV yaitu mikroba jenis (Bacillus sp).

\subsection{C/N rasio Kompos}

Hasil uji $\mathrm{C} / \mathrm{N}$ rasio belum memenuhi baku mutu seperti Gambar 3 dibawah ini. 
Sri Widyastuti dan Sardin : Pengolahan Sampah Organik Pasar dengan Menggunakan Media Larva Black Soldier Flies (BSF)

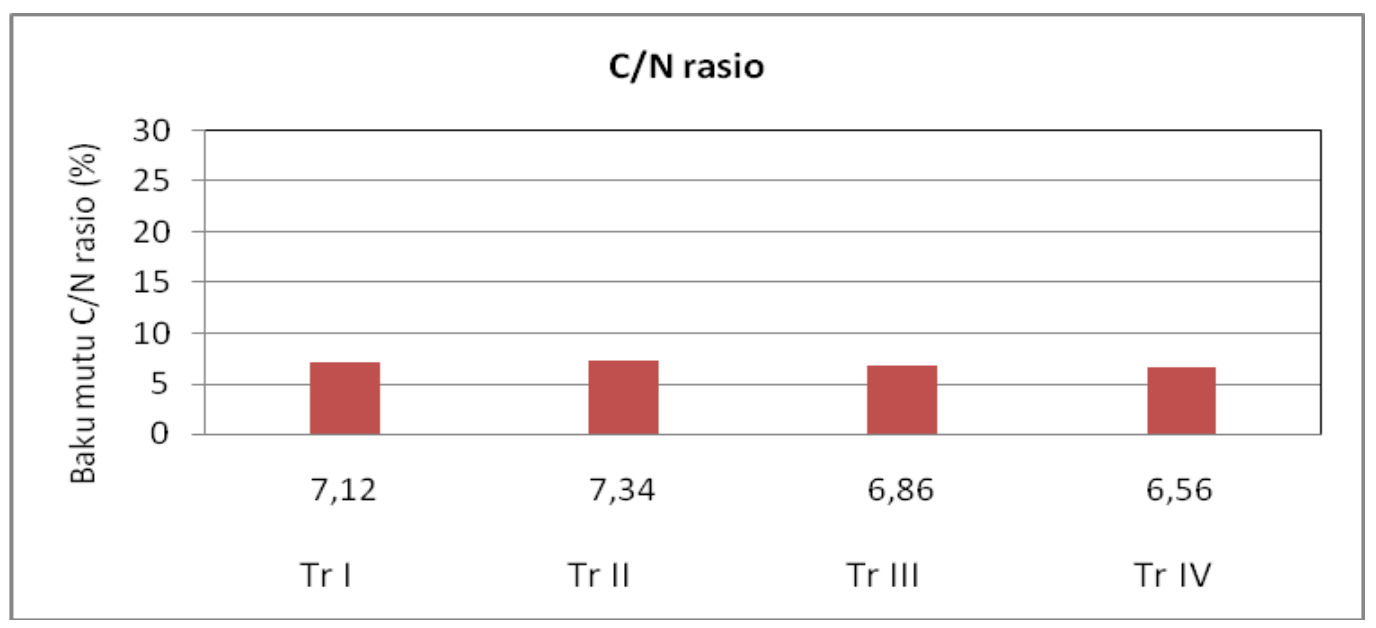

Gambar 3 Analisis C/N Rasio Kompos Sampah Pasar

Dari hasil analisis $\mathrm{C} / \mathrm{N}$ rasio kompos sampah pasar pada semua treatment itu belum memenuhi baku mutu yang disyaratkan dalam SNI 19-7030-2004, 2004, Spesifikasi Kompos dari Sampah Organik Domestik yaitu sebesar 10-20.

Nilai $\mathrm{C} / \mathrm{N}$ rasio yang rendah dikarenakan residu hasil biokonversi larva BSF belum melalui proses pengomposan yang sempurna. Kompos sebagai residu hasil biokonversi sebelum di analisis harus melalui tahap didiamkan selama beberapa hari karena residu biokonversi belum stabil. Menurut Widarti, dkk. (2015), pada proses pengomposan nilai rasio $\mathrm{C} / \mathrm{N}$ mengalami penurunan disebabkan oleh terjadinya penurunan jumlah karbon yang dipakai sebagai sumber energi mikroba untuk mendekomposisi material organik. Pada proses pengomposan, berlangsung perubahan perubahan bahan organik menjadi karbon dioksida : $(\mathrm{CO} 2)+$ air $(\mathrm{H} 2 \mathrm{O})+$ nutrien + humus + energi. Selama proses pengomposan, $\mathrm{CO} 2$ menguap dan menyebabkan penurunan kadar karbon dan peningkatan nitrogen, sehingga rasio $\mathrm{C} / \mathrm{N}$ kompos menurun.

\subsection{Kelembaban Kompos}

Hasil uji Kelembaban belum memenuhi baku mutu seperti gambar ( Gambar 4).

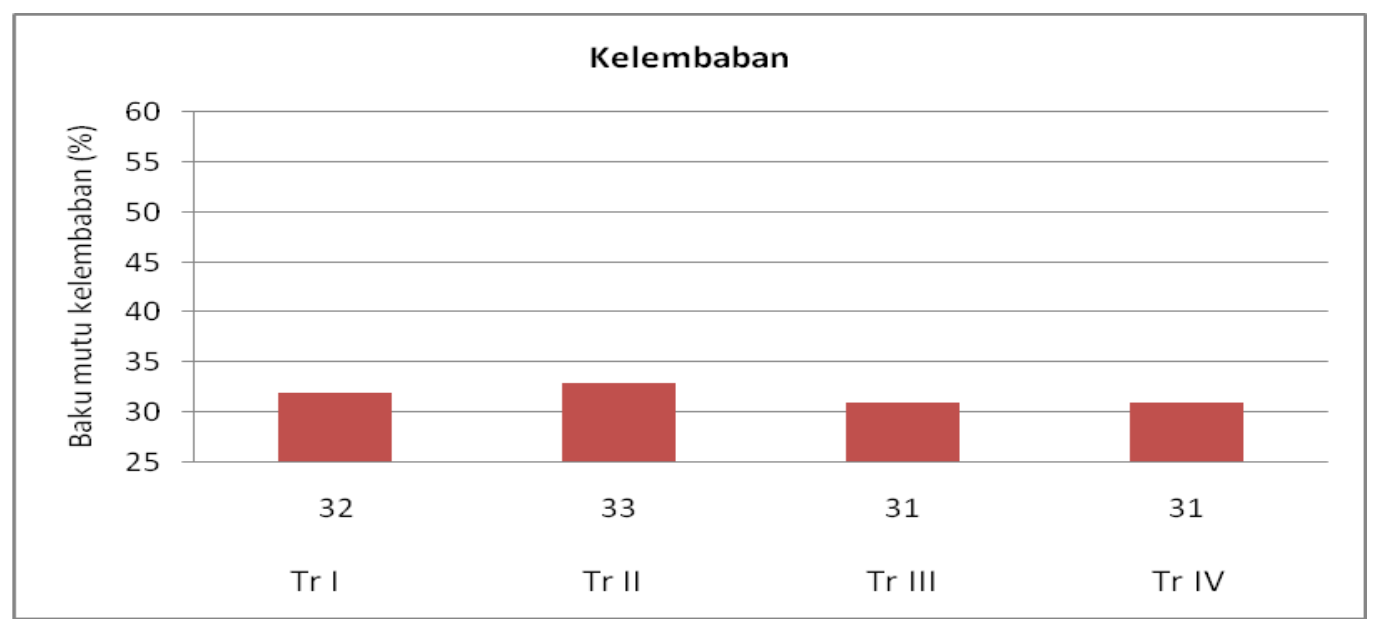

Gambar 4 Analisis Kelembaban Kompos Matang

Dari hasil analisis Kelembaban kompos sampah pasar dari semua treatment belum memenuhi baku mutu yang disyaratkan dalam SNI 19-7030-2004 yaitu sebesar 50-60\%. 
Fatchurochim, dkk. dalam Hakim (2017) melakukan penelitian terhadap pengaruh kadar air dalam pakan black soldier fly. . Hasil penelitian tersebut menunjukkan bahwa larva black soldier fly masih mampu hidup pada pakan yang mengandung kadar air sebesar $20-90 \%$ dengan nilai survival rate (SR) rendah. Sedangkan, SR larva tertinggi tercapai pada pakan dengan kadar air $40-60 \%$.

Mikrooranisme dapat memanfaatkan bahan organik apabila bahan organik tersebut larut di dalam air. Kelembaban $40-60 \%$ adalah kisaran optimum untuk metabolisme mikroba. Apabila kelembaban di bawah 40\%, aktivitas mikroba akan mengalami penurunan dan akan lebih rendah lagi pada kelembaban $15 \%$. Apabila kelembaban lebih besar dari $60 \%$, hara akan tercuci, volume udara berkurang, akibatnya aktivitas mikroba akan menurun dan akan terjadi fermentasi anaerobik yang menimbulkan bau tidak sedap

\section{3. pH Kompos}

Hasil uji pH Kompos memenuhi baku mutu seperti gambar 5 .

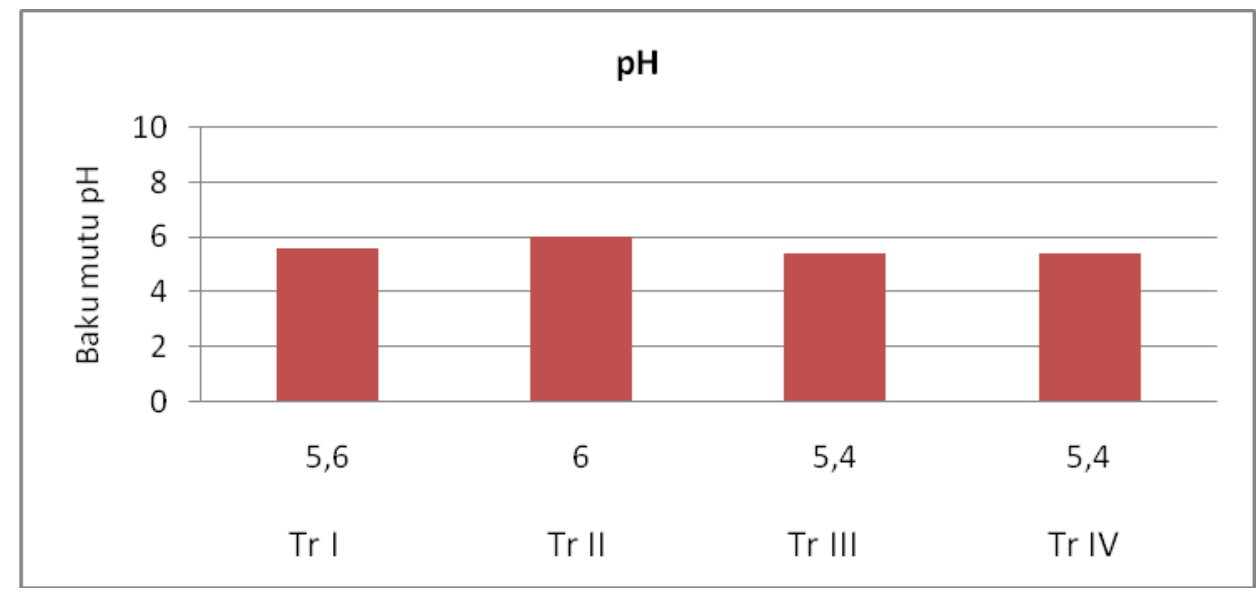

Gambar 5 Analisis pH Kompos Matang

Dari hasil analisis pH kompos sampah pasar pada semua treatment memenuhi baku mutu yang disyaratkan dalam SNI 19-70302004. Perubahan $\mathrm{pH}$ kompos berawal dari $\mathrm{pH}$ agak asam karena terbentuknya asam-asam organik sederhana, kemudian $\mathrm{pH}$ meningkat pada inkubasi lebih lanjut akibat terurainya protein dan terjadinya pelepasan ammonia (Supadma, 2008).

$\mathrm{pH}$ yang optimum untuk proses pengomposan berkisar antara 6.5 sampai 7.5. Proses pengomposan sendiri akan menyebabkan perubahan pada bahan organik dan $\mathrm{pH}$ bahan itu sendiri. $\mathrm{pH}$ kompos yang sudah matang biasanya mendekati netral. Menurut Tchobanoglous dalam Mentari (2018), kondisi pH harus memungkinkan untuk tumbuhnya bakteri dan jamur, sehingga proses degradasi oleh mikroorganisme juga dapat berlangsung. Jamur yang terdapat di sampah tumbuh optimum pada $\mathrm{pH} 5,6$, tetapi tetap dapat bertahan pada $\mathrm{pH} 2,0-9,0$.

Larva black soldier fly memiliki rentang toleransi $\mathrm{pH}$ yang cukup besar, sehingga larva dapat hidup pada kondisi lingkungan yang ekstrem (Suciati, 2017). Larva black soldier fly mampu menoleransi sejumlah inhibitor biologi dalam lindi microaerobic fermentation (MF), termasuk etanol, asetat, suhu, dan $\mathrm{pH}$ ekstrem. Larva toleran terhadap tingkat $\mathrm{pH}$ 0,7-13,7 dan mampu mengubah $\mathrm{pH}$ awal dari 2,7-12,7 menjadi antara 7,8-8,9, (Alattar, 2012).

Pada penelitian Kahar, et al (2020), setelah 2 minggu biokonversi sampah organi oleh larva black soldier fly, diperoleh pupuk organik (kompos) berwarna merah kehitaman dan agak berbau amoniak. Sedangkan, $\mathrm{pH}$ pupuk organik (kompos) tercatat berkisar 6,87-7,98, dengan nilai rata-rata 7,88. 


\subsection{Suhu Kompos}

Hasil uji suhu kompos melebihi baku mutu seperti gambar 6. Semakin tinggi temperatur akan semakin banyak konsumsi oksigen dan akan semakin cepat pula proses dekomposisi. Peningkatan suhu dapat terjadi dengan cepat pada tumpukan kompos. Temperatur yang berkisar antara $30-60{ }^{\circ} \mathrm{C}$ menunjukkan aktivitas pengomposan yang cepat. Suhu yang lebih tinggi dari $60^{\circ} \mathrm{C}$ akan membunuh sebagian mikroba dan hanya mikroba thermofilik saja yang akan tetap bertahan hidup. Suhu yang tinggi juga akan membunuh mikroba-mikroba patogen tanaman dan benih-benih gulma

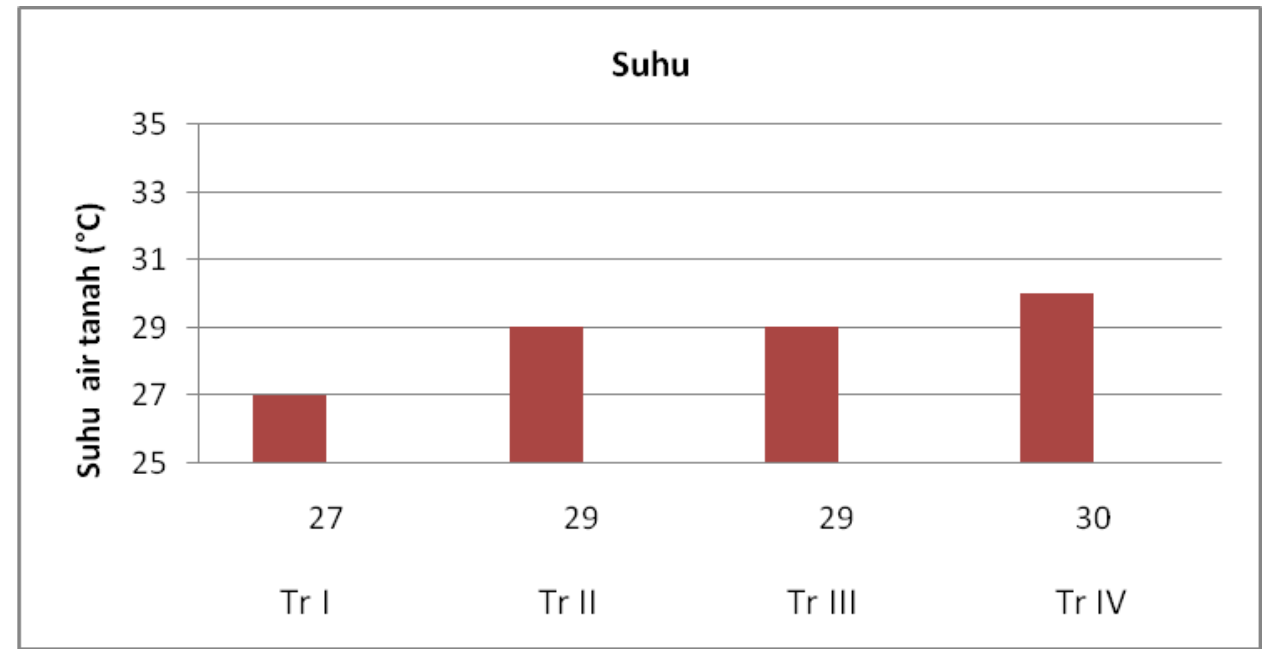

Tabel 6 Analisis Suhu Kompos Sampah Pasar

Berdasarkan hasil analisis, suhu kompos sampah pasar pada semua treatment melebihi baku mutu yang disyaratkan dalam SNI 19-7030-2004. Pengamatan suhu dilakukan untuk mengetahui perubahan aktivitas mikoorganisme karena suhu merupakan salah satu indikator dalam mengurai bahan organik. Pengamatan dilakukan pada beberapa titik dari tumpukan kompos agar memastikan kestabilan suhu kompos. Suhu kompos pada masing masing komposter meningkat dikarenakan adanya aktifitas bakteri mesofilik dan jamur mesofilik. Suhu kompos pada masing-masing komposter tidak mencapai fase termofilik (40 $-65^{\circ} \mathrm{C}$ ). Suhu kompos pada masing-masing komposter hanya berkisar antara $28^{\circ} \mathrm{C}-31^{\circ} \mathrm{C}$. Suhu yang tidak stabil serta tidak tercapainya fase termofilik $\left(40-65{ }^{\circ} \mathrm{C}\right)$ dikarenakan tumpukan bahan yang terlalu rendah akan membuat bahan lebih cepat kehilangan panas, sehingga temperatur yang tinggi tidak dapat tercapai.
Temperatur yang tinggi pada proses pengomposan sangat penting untuk proses higienisasi, yaitu untuk membunuh bakteri patogen dan bibit gulma. Selain itu juga untuk memacu proses pengomposan karena pada umumnya proses pengomposan kombinasi suhu termofilik dan mesofilik. Kurang tingginya suhu kompos disebabkan karena jumlah limbah yang dikomposkan tidak cukup memberikan proses insulasi panas. Sejumlah energi dilepaskan dalam bentuk panas pada perombakan bahan organik sehingga mengakibatkan naik turunnya temperatur. Peningkatan suhu dikarenakan adanya aktivitas bakteri dalam mendekomposisi bahan organik. Kondisi mesofilik lebih efektif karena aktivitas mikroorganisme didominasi protobakteri dan fungi. Pembalikan yang dilakukan dalam proses pengomposan mengakibatakan temperatur turun dan kemudian naik lagi (Pandebesie, 2012). 


\subsection{Jenis Mikroorganisme}

Hasil analisis jenis mikroorganisime kompos sampah pasar seperti tabel 1.

Tabel 1 Analisis Jenis Mikroorganisme Kompos Sampah Pasar

\begin{tabular}{cccl}
\hline No & Kode Sampel & Baku Mutu & \multicolumn{1}{c}{ Mikroorganisme } \\
\hline & & & Bacilus sp \\
1 & Treatment I & - & Pseudominas sp \\
& & & Saccharomyces sp \\
& & & Bacilus sp \\
2 & Treatment II & - & Pseudominas sp \\
& & & Saccharomyces sp \\
3 & Treatment III & - & Bacillus sp \\
4 & Treatment IV & - & Bacillus sp \\
\hline
\end{tabular}

Jenis mikroorganisme pada kompos ada 3 (tiga) yaitu (Saccharomyces, Bacillus $s p$, Pseudominas $s p$,) dan mikroba fungsional yang berfungsi untuk mendomposisi zat-zat organik pada sampah agar menjadi kompos. Mikroba Bacilus $s p$ merupakan bakteri dekomposer bahan organik untuk tumbuh dengan baik. Pseudominas sp (bakteri motil karena mempunyai flagela monortika), bisa tumbuh dengan mudah pada jenis media pembiakan, kadang-kadang berbau manis seperti anggur atau seperti bau corn taco, tumbuh pada suhu $37^{\circ} \mathrm{C}-42^{\circ} \mathrm{C}$. Mikroba fungsional yang diidentifikasi adalah mikroba fungsional protease (pengurai protein), amylase (pengurai karbohidrat) dan lipase (pengurai lemak).

Larva black soldier fly dapat mengurai bahan-bahan organik karena dalam saluran pencernaannya mengandung beberapa bakteri (Yu et al., 2011). Bakteri yang teridentifikasi dalam sistem pencernaan larva BSF, adalah Micrococcus sp, Streptococcus $\mathrm{sp}$, Bacillus $\mathrm{sp}$ dan Aerobacter aerogens (Wardhana, 2016). Penelitian Gold (2020) pada kedua substrat sisa makanan menunjukan, pemeliharaan larva black soldier fly menurunkan kekayaan bakteri dan mengubah sifat dan komposisi residu fisikokimia selama periode pemeliharaan 12 hari. Anggota tipikal mikrobiota usus larva (yaitu, Providencia, Dysgonomonas, Morganella, dan Proteus) menjadi lebih berlimpah, menunjukkan transfer mereka ke dalam residu melalui ekskresi. Penelitian di masa depan harus mengisolasi anggota taksa ini dan menjelaskan potensi sebenarnya mereka untuk memengaruhi kinerja pemeliharaan secara massal black soldier fly

\subsection{Lama Waktu Pengomposan}

Hasil analisis lama waktu pengomposan sampah pasar seperti gambar 7 .

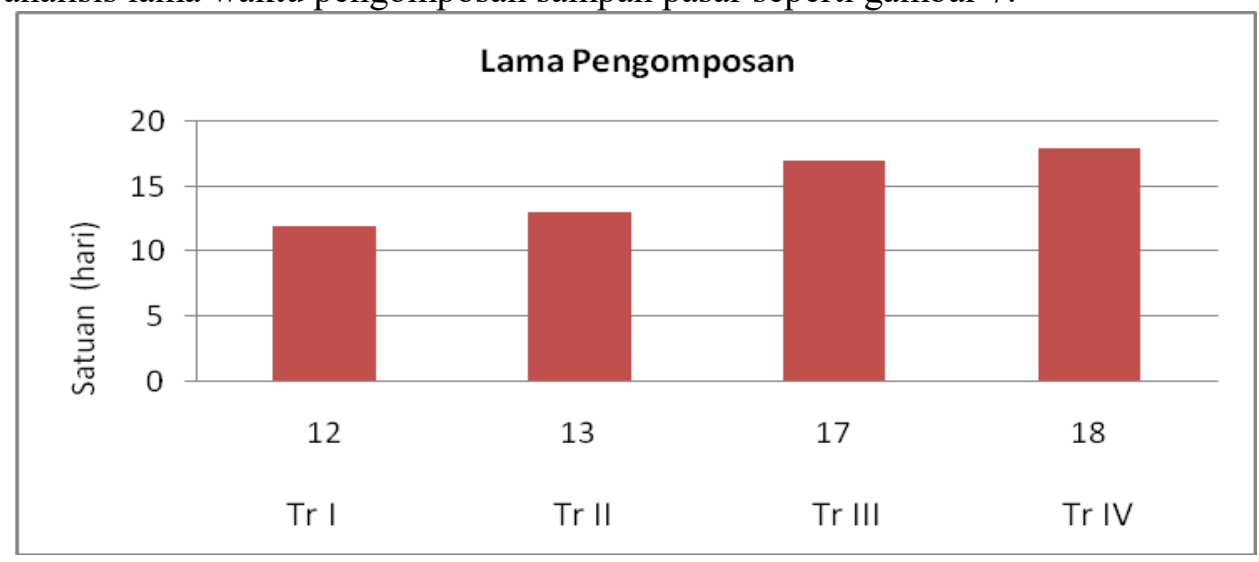

Gambar 7 Analisis Lama Waktu Pengomposan Sampah Pasar 
Hasil analisis tingkat kematangan kompos berdasarkan SNI 19-7030-2004 dengan kriteria suhu sesuai dengan suhu air tanah, bewarna kehitaman dan tekstur seperti tanah, berbau tanah adalah sebagai berikut Treatment I dan Treatment II membutuhkan lama waktu pengomposan selama 13 hari. Sedangkan treatment III membutuhkan lama waktu 17 hari dan treatment IV membutuhkan lama waktu 18 hari

Terjadinya penurunan kadar air ini disebabkan karena pelepasan air dari bahan organik yang terbuang dan karena proses perlindian pada masing-masing komposter. Kelembaban memegang peranan yang sangat penting dalam proses metabolisme mikroba dan secara tidak langsung berpengaruh pada suplai oksigen. Pada tahap awal pengomposan, mikroorganisma sangat aktif menyerap bahan organik, dimana hasil proses degradasi ini menghasilkan cairan (lindi). Hal inilah yang menyebabkan kandungan air belum berkurang secara nyata pada awal pengomposan. Sebenarnya kondisi kelembaban lebih besar dari $60 \%$ akan mencegah oksigen berpindah melalui masa sampah, sehubungan dengan porositas yang terjadi dipenuhi oleh air sehingga ruang udara bebas menjadi tidak ada, sehingga kondisi menjadi anaerobik. Kondisi ini akan menyebabkan proses pengomposan berlangsung lebih lama. Di sisi lain, jika kelembaban terlalu rendah, efisiensi degradasi akan menurun karena kurangnya air untuk melarutkan bahan organik yang akan dideradasi oleh mikroorganisma sebagai sumber energinya (Pandebesie, 2012).

Gabler (2014) menyebutkan bahwa penggunaan black soldier fly bukan hanya mampu menghasilkan pakan ternak namun juga mampu menghasilkan pupuk kompos. Penelitian Lena Monita, et al (2017) menunjukkan adanya kompos dan residu kompos pada semua perlakuan. Residu kompos merupakan bagian sampah organik yang ber struktur kasar yang tidak bisa di cerna dan tidak di sukai oleh black soldier fly. Hasil penelitian Anggraeni (2010) menyebutkan bahwa pemupukan pada tanaman kacang panjang dengan menggunakan kompos hasil peruraian black soldier fly pada limbah Palm Kernel menunjukkan hasil yang positif pada pertumbuhan tanaman kacang panjang. Pupuk kompos hasil peruaraian limbah palm kernel mampu meningkatkan panjang batang, jumlah cabang batang, jumlah daun, luas permukaan daun, kandungan klorofil, jumlah bunga, jumlah buah, dan panjang buah.

Penelitian Mega Trishuta Pathiassan, et al (2020) menyebutkan jenis dan jumlah sampah akan menentukan nilai biomassa larva, nilai konsumsi substrat, dan nilai indeks reduksi sampah. Jenis sampah juga nilai tingkat ketahanan hidup larva black soldier fly. Penelitian ini juga menyebutkan pupuk organik yang dihasilkan dari biokonversi black soldier fly memenuhi standar persyaratan teknis pupuk organik padat berdasarkan Permentan No. 70/Permentan/SR.140/10/2011.

Larva black soldier fly Hermetia illucens (Diptera: Stratiomyidae) sangat tepat untuk di gunakan sebagai teknologi pengolahan sampah organik berbasis serangga. Teknologi ini sebagai salah satu bentuk pengelolaan sampah melalui konsep 3R untuk mengurangi jumlah sampah organik sejak dari sumbernya . Larva black soldier fly mampu menguraikan sampah organik selama 10-11 hari dengan menghasilkan nilai tambah berupa kompos, dan biomassa larva atau prepupa berpotensi sebagai pakan bernutrisi yang baik

\section{KESIMPULAN}

Hasil karakteristik kompos sampah pasar yang diolah dengan menggunakan larva black soldier fly, menunjukkan bahwa treatment penjemuran selama 2 hari lebih baik dibandingkan dengan penjemuran selama 3 hari. Beberapa parameter yang di uji seperti $\mathrm{C} / \mathrm{N}$ rasio, suhu dan kelembaban belum memenuhi baku mutu sesuai SNI 19-70302004. Spesifikasi Kompos dari Sampah Organik Domestik . Hanya pH yang memenuhi baku mutu sesuai SNI19-70302004. Spesifikasi Kompos dari Sampah Organik Domestik.

Penambahan kompos stater pada media pengomposan membantu proses pengomposan satu hari lebih cepat dibandingkan denagn ayng tidak di tambah dengan kompos stater. Jenis mikroorganisme pengomposan sampah pasar yang paling 
dominan ditemukan dalam penjemuran 2 hari dan 3 hari yaitu mikroba jenis Bacillus $s p$.

\section{UCAPAN TERIMAKASIH}

Ucapan terima aksih di sampaikan kepada Pengelola Pusat Daur Ulang Jambangan Kecamatan Jambangan Kota Surabaya dan Pengelola Pasar Puspa Agro (Sidoarjo) sebagai lokasi pembibitan BSF.

\section{DAFTAR PUSTAKA}

Abdul Kahar, Muhammad Busyairi, Sariyadi Sariyadi, Agus Hermanto, Ari Ristanti, 2020, Biconversion of Municipal Organic Waste Using Black Soldier Fly Larvae Into Compost and Liquid Organic Fertilizer, Konversi, Volume 9 No. 2, Oktober 2020, 35 - 40 e- ISSN: 2541-3481

https://ppjp.ulm.ac.id/journal/index.php/ko nversi/article/view/9176

Anggraeni, D. 2010. Pengaruh pemupukan bioconversion fertilizer palm kernel meal (BFPKM) terhadap pertumbuhan Vigna unguiculata L. Walp (Kacang Panjang) varietas Mutiara. Tesis. Program Pascasarjana, Universitas Indonesia, Depok

Alattar, M. A. 2012. Biological treatment of leachates of microaerobic fermentation. Tesis. Portland State University, Portland

Badan Pengkajian dan Penerapan Teknologi. 2010. Evolusi Teknologi Pengolahan Sampah (http://www.enviro.bppt.go.id/Berita /Data/25052010.htm diakses pada 4 Mei 2020)

Bullock, N., Chapin, E., Evans, A., Elder, B., Givens, M., Jeffay, N., Robinson, W. 2013. The black soldier fly how-toguide. UNC Institute for the environment. ENST.

Davis, S.C., W. Hay, dan J. Pierce, 2014. Biomass in the energy industry: An introduction. London (GB): BP p.l.c

Diener, S., Gutiérrez, F. R., Zurbrügg, C., \& Tockner, K. 2009. Are larvae of the black soldier fly-Hermetia illu-cens-a financially viable option for organic waste management in Costa Rica. Prosiding Seminar Sardinia.

Diener, S. 2010. Valorisation of organic solid waste using the black soldier fly,
Hermetia illucens, in low and middleincome countries. ETH Zurich,

Diener, S., S. Solano., R. Gutiérrez., C. Zurbrugg \& K. Tockner. 2011. Biological treatment of municipal organic waste using black soldier fly larvae. Waste and Biomass Valorization 2: 357-363

Dortmans B, Diener S, Verstappen B, Zurbrügg. 2017. Proses Pengolahan Sampah Organik

dengan Black Solier Fly: Panduan Langkah-langkah Lengkap. Octavianti DC. Dübendorf

$(\mathrm{CH})$ : Eawag-Swiss Federal Institute of Aquatic Science and Technology.

Fahmi, M. R., 2015. Optimalisasi proses biokonversi dengan menggunakan mini-larva Hermetia illucens untuk memenuhi kebutuhan pakan ikan. Prosidng Seminar Nasional Masyarakat Biodiversitas Indonesia 1(1), pp. 139-144

Fifi Fata'tiatul Hidayah, Destya Nurfrida Rahayu, dan Candra Budiman, 2020, Pemanfaatan Larva Black Soldier Fly (Hermatia illucens) sebagai Penanggulangan Sampah Organik melalui Budidaya Magot, Jurnal Pusat Inovasi Masyarakat Vol 2 (4) 2020: 530-534 ISSN 2721-897X

Gabler, F. 2014. Using black soldier fly for waste recycling and effective Salmonella spp. reduction. Theses. Swedish University of Agricultural Sciences, Swedish

Gani, A. 2007. Konversi sampah organik menjadi komarasca (kompos-arang aktif-asap cair) dan aplikasinya pada tanaman daun dewa. Disertasi. Sekolah Pascasarjana, Institut Pertanian Bogor, Bogor

Gobbi, P., A. Martínez-Sánchez, dan S. Rojo, 2013. The effects of larval diet on adult life-history traits of the black soldier fly, Hermetia illucens (Diptera: Stratiomyidae). Eur J Entomol 110 (3), pp. 461-468.

Hakim, A R., Prasetya, A., Petrus, Himawan, T B M. 2017. Studi Laju Umpan pada Proses Biokonversi Limbah Pengolahan Tuna menggunakan Larva Hermetia illucens. JPB Kelautan dan 
Perikanan. Vol. 12, No 2, Hal. 179192.

Harlystiarini. 2017. Pemanfaatan tepung larva black soldier fly (Hermetia illucens) sebagai sumber protein pengganti tepung ikan pada pakan puyuh petelur (Cortunix cortunix japonica). [Tesis]. Bogor (ID): Institut Pertanian Bogor.

Holmes, L., Vanlaerhoven, S., \& Tomberlin, J. 2012. Relative humidity effects on the life history of Hermetia illucens (Diptera: Stratiomyidae). Environmental Entomology, 41(4), 971-978.

Kim, W.T., Bae, S.W., dkk. 2010. The larval age andmouth morphology of the black soldier fly,Hermetia illucens (Diptera:Stratiomyidae). International Journal ofIndustrial Entomology. 21(2), 185-187.

Kusnadi., Sulasmi, A., Adisendjaja, H.Y. (2009). Pemanfaatan Sampah Organik Sebagai Bahan Baku Produksi Bioetanol Sebagai Energi Alternatif. Jurnal Biologi Universitas Pendidikan Indonesia.

Lena Monitaa , Surjono Hadi Sutjahjob , Akhmad Arif Aminc, Melta Rini Fahmid , 2017, Pengolahan Sampah Organik Perkotaan Menggunakan Larva Black Soldier Fly (Hermetia illucens) , Jurnal Pengelolaan Sumberdaya Alam dan Lingkungan Vol. 7 No. 3 (Desember 2017): 227234 doi: 10.29244/jpsl.7.3.227-234 227

Mega Trishuta Pathiassana, Syauqy Nur Izzy, Haryandi dan Samuyus Nealma, 2020, Studi Laju Umpan Pada Proses Biokonversi Dengan Variasi Jenis Sampah Yang Dikelola PT. Biomagg Sinergi Internasional Menggunakan Larva Black Soldier Fly (Hermetia Illucens), Jurnal Tambora Volume . 4 NO. 1 Februari 2020 , http://jurnal.uts.ac.id

Mentari, P. D. 2018. Karakteristik Dekomposisi Sampah Organik Pasar Tradisional menggunakan Larva Black Soldier Fly (Hermetia illucens). Skripsi. Bogor: Institut Pertanian Bogor.

Moritz Gold, Fabienne von Allmen, Christian Zurbrügg, Jibin
Zhang and Alexander Mathys, 2020, Identification of Bacteria in Two Food Waste Black Soldier Fly Larvae Rearing Residues, Front Microbiol 2020; 11: 582867

Published online 2020 Nov 23. doi: $10.3389 /$ fmicb. 2020.582867

https://www.ncbi.nlm.nih.gov/pmc/a rticles/PMC7719680/

Muhayyat, M. S., Yuliansyah, A. T., Prasetya, A. 2016. Pengaruh Jenis Limbah dan Rasio Umpan pada Biokonversi Limbah Domestik Menggunakan Larva Black Soldier Fly (Hermetia illucens). Jurnal Rekayasa Proses. Vol. 10, No. 1, hal. 23-29.

Pandebesie, E.S., Rayuanti, D., Pengaruh Penambahan Sekam Pada Proses Pengomposan Sampah Domestik. Jurnal Lingkungan Tropis, 2013, $6(1), 31-40$.

Popa, R. dan Green, T. 2012. DipTerra LCC e-Book 'Black Soldier Fly Applications'. DipTerra LCC.

SNI 19-7030-2004, 2004, Spesifikasi Kompos dari Sampah Organik Domestik, ICS 13.030.40 Badan Standardisasi Nasional

Subdirektorat Statistik Lingkungan Hidup, 2018, Statistik Lingkungan Hidup Indonesia 2018 Pengelolaan Sampah , Badan Pusat Statistik Indonesia

Suciati R, Faruq H. 2017. Efektifitas media pertumbuhan maggots Hermetia illucens (lalat tentara hitam) sebagai solusi pemanfaatan sampah organik. Jurnal Biosfer dan Pendidikan Biologi. Vol 2 (1): 8-13.

Tomberlin JK, Adler PH, Myers HM. 2009. Development of the Black Soldier Fly (Diptera: Strationmyidae) in Relation to Temperature. Environmental Entomol. 38:930934.

Varma, V. S., Das, S., Sastri, C. V., dan Kalamdhad, A. S. 2017. Microbial degradation of lignocellulosic fractions during drum composting of mixed organic waste. Sustainable Environment Research, 27(6), 265-272.

Wardhana, A.H., 2016. Black Soldier Fly (Hermetia illucens) sebagai Sumber Protein Alternatif untuk Pakan 
Ternak. Wartazoa Vol. 26 No. 2 Th. 2016, hal. 069-078. DOI: http://dx.doi.org/10.14334/wartazoa. v26i2.12 18.

Widarti, B. N., Wardhini, W. K., Sarwono, E. 2015. Pengaruh Rasio C/N Bahan Baku Pada Pembuatan Kompos dari Kubis dan Kulit Pisang. Jurnal Integrasi Proses. Vol. 5, No. 2, Hal. 75-80.

https://jurnal.untirta.ac.id/index.php/ jip/article/view/200/125

Yudi Sastro, 2016, Teknologi Pengomposan Limbah Organik Kota Menggunakan
Black Soldier Fly, Badan Pengkajian Teknologi Pertanian, BPPT. Jakarta Yu, G., Cheng, P., Chen, Y., Li, Y., Yang, Z., Chen, Y., Tomberlin, J.K., 2011. Inoculating poultry manure with companion bacteria influences growth and development of Black Soldier Fly (Diptera: Stratiomyidae) larvae. Environmental Entomology, February $201140: 30-35$. DOI: 10.1603/EN10126.

https://pubmed.ncbi.nlm.nih.gov/22182 $\underline{608 /}$ 